\title{
Social Business Education: An Interview With Nobel Laureate Muhammad Yunus
}

\author{
JILL KICKUL \\ New York University \\ SIRI TERJESEN \\ Indiana University \\ SOPHIE BACQ \\ Northeastern University \\ MARK GRIFFITHS \\ Miami University
}

In this interview, Nobel Laureate Muhammad Yunus outlines the role of social business education and its potential in teaching the next generation of social innovation leaders. Our questions and his responses focus on Yunus's experience, drawing on lessons learned from the Grameen Bank and his most recent educational endeavors, including the Yunus Centre and the Grameen Creative Lab. The interview begins with a discussion of the development and evolution of social business and its distinction from social entrepreneurship. Then, we move on to the role of faculty and community engagement and student qualities that should be sought and cultivated in social business education. Next, Yunus formulates recommendations for what business schools and educators can do to prepare students to recognize and implement new social innovations for their communities. We conclude by highlighting some of the challenges involved in incorporating Yunus's social business model into the capitalist economic paradigm that dominates in western business schools and by reflecting on implications for educators as well as the programmatic challenges in integrating social business concepts and initiatives into curriculum and pedagogy.

Born in 1940, Muhammad Yunus studied at Dhaka University in Bangladesh (BA, 1960; MA, 1961) and then joined the Bureau of Economics as a research assistant and was appointed as a lecturer of economics at Chittagong University. In 1965, he was offered a Fulbright scholarship to study economics at Vanderbilt University where, after receiving his $\mathrm{PhD}$ in economics (1969), he accepted a position as assistant professor at Middle Tennessee State University before returning to Bangladesh in 1972 as the head of the Department of Economics at Chittagong University.

Known as the "Banker to the Poor," Yunus established the Grameen Bank in Bangladesh in 1983. Motivated by his belief that credit is a fundamental human right, Yunus's objective was to help people escape poverty by providing loans on suitable terms and education based upon sound financial principles. Yunus and the Grameen Bank were jointly awarded the Nobel Peace Prize in 2006.

The Grameen Bank is an excellent example of what Yunus conceives as a "social business." To set the foundation for our interview, we highlight that Yunus defines a social business as being based on the following seven principles (World Economic Forum in Davos, January 2009):

1. The objective of the business is to overcome poverty, or one or more intractable problems

\footnotetext{
${ }^{1}$ Yunus makes the point that the providers of capital are also motivated by intrinsic returns, namely, addressing and (hopefully) resolving a social objective.
} 


\section{Motivated by his belief that credit is a fundamental human right, Yunus's objective was to help people escape poverty by providing loans on suitable terms and education based upon sound financial principles.-Kickul, Terjesen, et al.}

of society (such as education, health, technology access, and environment); it is not profit maximization.

2. It must be financially and economically sustainable.

3. Investors receive a return on investment that does not exceed the amount of their investment, that is, no dividend is given.

4. When funds are repaid by the borrower, any and all the company profit (i.e., loan interest) is retained by the company for additional expansion and improvement.

5. The business must be environmentally conscious.

6. The workforce should get market wages with better working conditions.

7. "Do it with joy."

In the light of these seven principles, Yunus (2010: 4) clearly distinguishes a social business from social entrepreneurship:

Social entrepreneurship relates to $a$ person. It describes an initiative of social consequences created by an entrepreneur with a social vision. This initiative may be a non-economic initiative, $\alpha$ charity initiative, or a business initiative with or without personal profit. ... In contrast with social entrepreneurship, social business is a very specific type of business- $a$ non-loss, non-dividend company with a social objective. A social business may pursue goals similar to those sought by social entrepreneurs, but the specific business structure of social business makes it distinctive and unique.

The social business concept is not without controversy, especially in capitalist economies, primarily because of its insistence on no financial return to risk-based capital, which is at odds with the basic capitalist paradigm underlying the curriculum at most, if not all, western business schools. Further, as is well-established (Alchian \& Demsetz, 1972; Hansmann, 1988; Jensen \& Meckling, 1976) both for-profit corporations as well as nondividend institutions suffer from agency problems, that is, the behavior of managers that is at odds with the goals and objective of the principals. We expect this potential separation of oversight between investors and management to pose additional challenges for the conduct of a social business, especially for the business students trained in the west. Thus, despite the apparent relation of social business to social entrepreneurship, which is generally characterized as "doing well by doing good," in which profitability and the personal gain of the principal is deemed the key to sustainability, the two concepts are fundamentally different on these issues.

Therefore, in the first part of the interview, we began by asking Yunus to provide his definition of the difference between social entrepreneurship and social business, and to recount the journey that led him to the concept of social business. Next, we wanted to know whether he saw any traits that distinguish social business leaders from social entrepreneurs and then probed for a distinction between an individual who provides funding and an individual who runs and manages a social enterprise. Our purpose was to investigate whether there were different educational requirements for these two types of individuals.

The second part of the interview explores the topic of social business education, with questions centered on the key characteristics, behaviors, and experiences that should be sought or developed in individuals to run social business centers at universities. We asked Yunus his opinion of the biggest mistakes or oversights that faculty and administrators could make when developing such $\alpha$ community. It was in this second part of the interview that the stark difference between the paradigm of western business schools and Yunus's vision of social business became most apparent.

This led naturally to the third part of the interview, in which we asked about the nature of a social business curriculum, how to develop the next generation of social innovation leaders, and whether the concept of social business was universal or context and economy specific. Here again, Yunus's vision is much more idealistic and universal, to the point of not recognizing differences in culture and economic context. We then asked Yunus how we, as educators, can motivate our students to pursue their ideas for social change, and ultimately change the world. What surprised us was that despite arguing in his book, Building Social Business, that all business schools should offer an MBA degree in social business and despite his U.S.-based training and teaching, Yunus believes that the next generation of social innovators should not be interested in making money (see below), saying that "social business is totally de- 
linked from the very idea of making personal profit." To us, this represents a fundamental disconnect from the economic paradigm underlying most, if not all, western business schools and applying this view to the typical business school curriculum may present some important challenges. We return to this issue in our discussion.

\section{THE CONCEPT OF SOCIAL BUSINESS}

\section{Over the past two decades there has been an} incredible increase in the interest in and practice of social entrepreneurship. In fact, you are one of the most revered individuals in this field because of your groundbreaking work in microfinance through the Grameen Bank. Now you have brought even more innovation through your advocacy of social business. How do you distinguish between social entrepreneurship and social business?

Social business is a type of business with the aim to change the world, a business driven by creativity and passion for problem solving. I call this new type of business "social business," because it exists for the collective benefit of others. It is a business whose purpose is to address and solve social problems, not to make money for its investors. It is a non-loss, non-dividend company. The investor can recoup his investment capital, but beyond that no profit is to be taken out as dividends by the investors. These profits remain with the company and are used to expand its outreach, to improve the quality of the product or service it provides, and to design methods to bring down the cost of the product or service.

Social business is a business where you do not want to make money for yourself, but you solve the problem with the business model. This is not the case for social entrepreneurship. A social entrepreneur may not be involved in a business at all, it could be just helping your neighborhood, improving healthcare, helping people to do that in a new way. Also this includes giving out dividends to the investors, which is not at all the case for social business. I would rather stick with social business because if you want to solve a social problem, you should not think of your benefit but think how to solve the problem most efficiently.

\section{How did your education and early experiences shape your interest in social entrepreneurship and then lead you to social business?}

I would stick to social business. Once we get into social entrepreneurship, we will digress into something different from social business. The concept of social business came to my mind through my experience with the Grameen companies. The first social business that I started was Grameen Bank in 1983 to help address the problem of poverty in my country, Bangladesh. In order to help the poor and to give them access to credit-which no other financial institution wished to do-I had to redesign the ways banks operate.

When I started teaching at the University of Chittagong, I started seeing real people in that village-not like in the textbooks, where you imagine people behaving in a certain way. These were not imaginary people, these were real people with everyday problems. And it excited me that, for the first time, I got the feel of people and their problems, and I could do something about it. A field trip to a village with my students yielded some insight into this quandary: There, I met a woman who made bamboo stools, but she earned just 2 cents for each. She told me and the class that if she could save 20 cents to buy her own supply of bamboo, she would not have to borrow from the dealer who sold it to her; because she owed him money, he was allowed to dictate the price of each stool she sold.

Then I thought to devise a project that would loan money to such struggling entrepreneurs, and then track their success rate. Gradually I launched the collateral-free microcredit project in 1976 and founded Grameen Bank in 1983 to provide banking services targeted at the poor, especially poor women. After more than 30 years, Grameen Bank has become an international organization, and microcredit has become a worldwide phenomenon in almost all countries of the world. I never imagined what I started out in the village of Jobra to solve a local problem would become a global movement. Now apart from Grameen Bank, we have started many other social businesses as well, which are working to solve various other social problems, be it health, education, technology access, or even environmental issues.

Within an educational context, recognizing that both social business and social entrepreneurship pursue similar goals in addressing social issues, are there certain traits that distinguish social business leaders from social entrepreneurs?

Yes, as I mentioned earlier, the social entrepreneur may not be involved in a business at all, he or she may be helping to solve a problem from a distance, but a social business leader will pick a problem, design a business to solve that problem, and take 
it from there-he or she will not just give the money and sit for the results to come.

Do you make a distinction between an individual who provides funding and an individual who runs and manages a social enterprise? If so, does this suggest very different motivations and educational requirements for these two types of individuals?

A person who provides funding may not be directly involved with running a project, I would say such a person is taking the initiative to solve a problem; one who manages and runs a business has to take charge of the day-to-day responsibility. As the latter is more involved, that person can enjoy the joy involved in a social action. The one who provides funds wants to do something for others, and so invests money, and takes the risk. That person is an entrepreneur. The enjoyment comes from solving a social problem. There is no educational requirement for the entrepreneurs. Executives may need professional, academic, and practical experience, as the job requires.

\section{SOCIAL BUSINESS EDUCATION: KEY ELEMENTS TO SUCCESS AND PITFALLS TO AVOID}

\section{From your work with Grameen Labs, Social \\ Business Workshops, and other educational institutions, how has the role of social business education developed and evolved?}

Social business is spreading quickly around the world. Bangladesh is showing the way and many others have been following that path quite eagerly. Like France-they have created a social business chair in a business school, and many of the French companies are participating in social businesses. We are even talking of social business in the context of the G20; during France's presidency of the G20, they want to promote the concept of social business.

We also have a Social Business Centre in Glasgow in collaboration with the Glasgow Caledonian University, which has the aim to transform the lives of the poorest through pioneering research examining the relationship between social business and health improvement. There are many others like this, for example, the Yunus Centre at AIT, Gromeen Creative Lab in Germany, and at Kyushu University in Japan, California State University Channel Islands (CSUCI), Asian University for Women (AUW), and University of Florence. These partnerships, in place between universities around the world and the Grameen Organization, represent a powerful force for change; especially the opportunities with universities represent the exchange of ideas, shared learning, and experience across nations and the promotion of findings that could lead to positive outcomes for society. As the missions of these partnerships illustrate, new research strands unlock the impact of social business and support systems in place to help those social businessmen and women who are already invoking the concepts of social business in practice. All this is part of a global movement that is growing fast, which promises much and which builds upon concepts and work that has emerged from Bangladesh.

How should we find or develop individuals to run social business centers at universities? What key characteristics, behaviors, and experiences should be sought?

The profile of a leader of a social business center should include entrepreneurial creativity-the ability to see needs and opportunities and to seize them. Academic competence will be an essential feature. In addition, the person should have the ability to inspire young people to unleash their creative instincts. He or she must show strong initiative in getting together different student groups with a variety of interests in order to work together on the same goal-that is, social business-and bring dynamism to the center. $\bar{A}$ faculty member may come from any discipline and join the field of social business. There should not be any constraints because social business is all about creating new ideas for solving social problems. The person needs to be an organizer. The educators can include courses, workshops, and create social business centers or clubs at their universities. Universities should be careful in choosing their faculty, and choose someone who knows about social business thoroughly.

What are the biggest mistakes or oversights that faculty and administrators could make when developing a community of social businessmen and women? Can you provide a specific example?

The distinction between social business and conventional business, that is, money-making business, is social business is totally de-linked from the very idea of making personal profit. It is very important to underline the words "very idea." Because once you keep the idea of profit, you get back to the old logic. So I would insist the faculty 
work extra hard to stay away from that logic. You create a new logic when you are in a social business. It is not simply doing another business. You belong to a completely new logical structure.

The biggest mistake or oversight would be to remain unsure about the distinction between social business and all other related concerns, such as social entrepreneurship, corporate social responsibility (CSR), social enterprise, social investment, and so on. It is a slippery slope. One has to be absolutely clear about what social business is. No room for confusion should be allowed.

Many faculty might take social business as a kind of CSR activity. They might think this is why big businesses are interested. Again make sure the candidate does not mix social entrepreneurship with social business. Social entrepreneurship does not always relate to business. Social entrepreneurship mostly is demonstrated through NGO activities. You have done something to solve the problem, helped people, you take the initiative. Social business is a special subset of the social entrepreneurship. It is a very clear domain, where certain conditions have to be fulfilled. The faculty should always remember this while teaching at the class for developing future social leaders.

\section{THE INTERDISCIPLINARY NATURE OF THE CURRICULUM AND THE POWER OF COLLABBORATION}

In your book, Building Social Business, you recommend that all business schools should offer an $M B A$ degree in social business. Other than the small projects and community outreach mentioned earlier, what should be included in this degree's curriculum, pedagogy, and other experiences?

Business schools should offer the MBA degree in social business for teaching social business models. Curriculum would focus on teaching business students about businesses to solve problems without having any intention of making personal financial gain for the investors. How do you conceptualize it, how do you prepare the business plan, key performance indicators (KPIs), how do you measure successes, failures-how do you monitor ... what would be the management style?, How do you grow, how do you compete, what does competition mean to you, how and when do you collaborate, and what kind of personnel you recruit?

\section{If you could change anything about how we} develop the next social innovation leaders, what would you recommend? What implications does your recommendation have for educators within and outside the business school (that is, schools of education, engineering, law, media, medicine, and public policy)?

My recommendation would be to teach the next generation of social innovators that business can be created without being interested in making money. We must emphasize civic commitments from students in all areas. Every learning experience must be accompanied with experiences in the community. Schools must teach holistic learning, students must be taught to look beyond their specific fields, to use knowledge and experience combining different areas, using their imagination and creativity, to solve the problems of society. All disciplines of knowledge are relevant to social business. Everybody has things to contribute.

What can business schools and educators do to better prepare students to become leaders who are equipped to recognize and develop new social innovations for their communities? How can we help ensure that our students develop sustainable innovations for long-term social and economic value creation? What types of collaborations should business schools develop with stakeholder sectors, such as the community. government, and the corporate world? How can such collaborations be developed and maintained?

Educators have to let the students choose their option. As students grow up, they will think about what kind of company they will invest in and what kind of company they will work for. Here, the schools have a special role to play. They should create awards for the students to recognize social businesses that reach and empower the most destitute and marginalized people. Also, in order to help students to work for long-term solutions, the schools must establish funding streams that are plentiful. Again, the schools should be careful in choosing the faculty and should not leave it to people who do not understand social business and its original mission and vision.

Again, the business schools can engage their students in small projects where they can choose a subject and create a solution of course. They can engage their interdisciplinary research team within and outside the university to solve targeted social issues and create global joint research opportunities utilizing their knowledge of social business. The aim should be financial and economic sustainability, but, importantly, any surplus that is generated by the business through the students 
should be redirected to the social mission or towards meeting some other social challenge rather than distributed as a dividend. They can collaborate with the community as well as large multinational corporations (MNCs) to get support for social business ideas from students, companies, and individuals so that the ideas can move into a practical phase. Not only that, but the business schools can conduct social business workshops and symposia, and deliver lectures to companies, governments and other external organizations to spread the word of social business.

\section{Recent research from the Global}

Entrepreneurship Monitor indicates that social entrepreneurship varies across countries. Do you think social business education should differ by region, culture, country, or level of education?

In principle social business should not be different in two different countries-no matter how different they are in terms of economic and technological standing. They should be based on same principles, operate with same commitment, and hope for a great achievement in reaching the goal. But the selection of social problem may be very different in different countries. At best, differences perhaps will come in the design of the business. In each case it is the innovativeness of the visionary designers which will make all the differences.

You have been an educator and activist for over 40 years. If you could change anything about how we develop the next social innovation leaders, what would you recommend?

Now, everyone has the capacity to change the world. Each one of us has the capacity to change the world because it is a world of ideas. All you have to do is come up with on idea, an idea for solving a specific problem. Without an idea, you will never start.

Now, everyone has the capacity to change the world. Each one of us has the capacity to change the world because it is a world of ideas.-Yunus

\section{DISCUSSION}

Reflecting on our interview, we highlight and emphasize the following points regarding the interdisciplinary initiatives in university programs, the methods of teaching social business and social entrepreneurship, the social MBA degree and its fit with the current business school paradigm, and the variety of social entrepreneurship around the world.

Yunus's many initiatives in social business education, in the development of programs, the Yunus Centre, and workshops and labs are designed to inspire and develop social innovation leaders. Yunus clearly recognizes the importance of the university environment to nurture the development of social business initiatives and the increased blending of the social and business realities. For example, the Grameen Creative Lab Workshop brings in professors and students across the university as well as practitioners and policy makers within the social business community. According to Yunus, this "intellectual infrastructure" has the power to provide thought leadership and is a vital catalyst for encouraging social business experimentation.

There are many similarities in the methods of teaching social business and social entrepreneurship. While social entrepreneurship has been described with differing degrees of specificity (Dacin, Dacin, \& Matear, 2010), we see social entrepreneurship as a process of social value creation in which resources are combined in new ways to meet social needs, stimulate social change, or create new organizations (Mair \& Martí, 2006). Thus, if we agree that both social entrepreneurship and social business share the same basic purpose, many of the suggestions proposed by Yunus can be directly applied to the social entrepreneurship classroom. There are many ways of infusing social entrepreneurship into education (Tracey \& Phillips, 2007), and several of these are consistent with the pedagogical methods mentioned by Yunus including workshops, symposia, speakers from a variety of social, business, and government sectors, and projects or internships with other social innovators and practitioners.

However, while social entrepreneurship involves processes that are unique to entrepreneurship to achieve aims that are distinctly social, regardless of the presence or absence of a profit motive (Short, Moss, \& Lumpkin, 2009), many business school students enter social entrepreneurship and innovation programs with differing motives and goals. While students may focus on a particular social problem or challenge, they may differ in their beliefs of the economic goals and incentives of the social firm. Nonetheless, all are taught the importance of long-term profitability for the purposes of sustainability and the importance of 
corporate governance for the preservation and appropriate allocation of scarce resources.

Yunus's general concept of a social business is one where investors are limited to a return of invested capital only, arguing that any dividend above the original investment would trump social objectives. Yunus's sixth principle of social business is that the workforce should get market wages with better working conditions. This indicates that Yunus values the basic management or business practices taught in business schools and recognizes that to attract the necessary managerial expertise for social businesses, social businesses must compete for talent with for-profit commercial enterprises. However, he does not view the same economic concept as applicable to the providers of funds.

The social business constraint of no additional returns runs counter to basic economic risk-return principles. Approximately $16 \%$ of nonprofit businesses fail within the first 5 years (National Center for Charitable Statistics [NCCS], 2011), with another $8-10 \%$ in danger of failing (Ottenhoff, 2010), compared to about $50 \%$ of all firms (Knaupp, 2005; Small Business Administration [SBA], 2011). Thus, for every four firms founded by a serial entrepreneur, at least one, if not two or three, will fail. Since each start-up requires a tremendous amount of personal investment of time and money, if the individual cannot earn a financial return on the successful business to compensate for the risk and expense taken in developing all of the failed businesses, this potential entrepreneur will lack the incentive to take the necessary risk because there is no financial upside to the personal investment and they would be worse off financially. This would lead to fewer social businesses being created by individuals.

In the Yunus social business model, the providers of capital must expect either the loss of capital or its (principal only) return over time which, when considering the time value of money, represents an opportunity loss. ${ }^{1}$ Yunus's insistence on market wages for the management team combined with a no-dividend policy for the suppliers of capital raises a second issue when teaching management theory and practice, namely the problem of agency costs.

In the wake of Enron, WorldCom, Tyco, Global Crossing, and other corporate scandals, business schools have devoted considerable time, effort, and resources in teaching and training students on

\footnotetext{
${ }^{1}$ Yunus makes the point that the providers of capital are also motivated by intrinsic returns, namely, addressing and (hopefully) resolving a social objective.
}

the concepts of corporate governance. As Manne (1999: 1) points out:

For-profit corporations have well-defined owners (shareholders), well-defined goals (profits), clear voting rights for owners to remove managers, clear signals about performance (profits and stock prices), a market for corporate control, and a market for managers. Owners thus retain both the ability and the incentive to monitor their agents, and agents are constrained in their behavior both by shareholder monitoring and by second-order markets. Furthermore, the cost of these mechanisms is relatively low because they are self-enforcing.

Nonetheless, many problems still remain, as can been seen from the most recent financial crisis. The problem becomes even more difficult in the nondividend world where owners are not welldefined; their voting rights are questionable or nonexistent; charitable goals are ambiguous or, at least, difficult to quantify; no significant secondorder markets operate; and residual claimants are either unable to monitor efficiently or are unwilling to do so (Manne, 1999).

In any businesses, it is imperative that there be appropriate supervision over the efficient allocation of resources. Normally, this is done through the oversight of senior management (the agent) by the board of directors that represents the interests of the principal. Unfortunately, in most western economies, the solution to agency problems in a not-for-profit context has been to rely almost exclusively on broad legal and legislative remedies, because the nonprofit firm does not lend itself to self-control. Control has to come, if at all, through statutory regulation and lawsuits. For an excellent discussion of this issue, see Manne (1999).

It follows then, that as Jensen and Murphy (1990: 141) argue "compensation should be structured for outstanding performance and meaningful penalties for poor performance" should be in place. Absent such controls, Jensen and Meckling (1976) predict that managers would be tempted to consume perquisites at the expense of the providers of capital. The issue here is that the compensation package should bring the actions of the social business manager in line with the best interests of the principals. However, in the social business model, it is not clear who the principal of the firm is. Without doubt, the board of directors must now answer to a multitude of constituents, including the communities being served as well as the providers of capital. Thus, the problem becomes one of optimal 
contracting between the agents and the principals. Supervision and compensation mechanisms outside the usual governance mechanisms recommended by agency theory for for-profit entities need to be designed to orient the agent's actions toward social impact. As Manne (1999: 228) points out, "it ... takes a great deal of faith on the part of potential donors, beneficiaries and founders to think that altruism and the non-distribution constraint are sufficient to overcome the agency problem inherent in the nonprofit firm."

If, as Yunus argues, the interests of the principals should not lie in making personal profit but rather in social good, then different measures of performance are needed. In the world of social business and social entrepreneurship, this has led to the recognition of the importance of measuring social impact and "impact investing." While there are several tools and resources for assessing social impact (see Foundation Center, 2011), this topic is largely unaddressed in most western business schools that do not address social issues.

Finally, recent research on social ventures in 49 countries (Lepoutre, Justo, Terjesen, \& Bosma, 2012; Terjesen, Lepoutre, Justo, \& Bosma, 2012) suggests that the prevalence and type of social entrepreneurial activity varies tremendously around the world. For example, compared to Latin America, south-east Asian countries (China, Hong Kong, and Korea) have higher prevalence rates of for-profit social enterprises and economically oriented hybrid enterprises. Yunus argues "social business should not be different in two different countries-no matter how different they are in terms of economic and technological standing." Economist Baumol (2010) points out that there are four basic types of capitalism: (1) state-guided capitalism in which the government tries to guide the market (e.g., banks in China, India, Japan, and Germany); (2) oligarchic capitalism in which the bulk of power and wealth is held by a small group of individuals and families (e.g., the old Soviet Bloc, Latin America, Arabic Middle East); (3) big-firm capitalism in which the most significant activities are carried out by established giant enterprises (e.g., continental Europe, Japan, Korea, pockets of the United States); and (4) entrepreneurial capitalism in which a significant role is played by small, innovative firms (e.g., Ireland, Israel, and pockets of the United Kingdom and United States). Hence, it is eminently possible that the opportunities for social investment and the vehicles with which they are launched in the United Kingdom or United States are vastly different from those that exist in Bangladesh where Grameen Bank was founded. This has clear implications for educators who work across countries and will need to teach about different types and levels of funding as well as the measurement and communication of firm social and economic value.

Yunus expects that the management of social businesses will become a key element in the education of business students and that the most appropriate way to convey the social business concept will be to earn a "social MBA" degree. Yunus (2010: 166) predicts that "the universities that move first to add this component (social MBA degree) to their curriculum will attract many of the world's brightest and most idealistic students." The role played by schools other than the business school, especially law schools, with respect to the corporate control of nonprofit entities highlights the necessary interdisciplinary nature of social business education and the structure of social business education outside the university walls (e.g., government involvement, private companies' partnerships).

We suspect, however, that for the reasons stated above, the Yunus social business model may not be easily incorporated into the paradigm of western economies' business schools and that important challenges will need to be overcome in order to "create a new logic." To our knowledge, the only social business centers at universities are the Yunus Centre at the Asian Institute of Technology in Bangkok, California State University's Institute of Social Business, and Kyushu University's Grameen Technology Lab in Japan. These programs share a willingness to advance the concept of social business through the development of new curricula and research opportunities, the creation of social venture funds, and the organization of universitywide social business plan competitions.

This roises another issue of some concern, namely where to locate, recruit, and retain the faculty qualified to teach courses in social business. As Yunus points out in the interview, "academic competence will be an essential feature." At the same time, these individuals must know "about social business thoroughly," even though this is still an emerging concept. The conundrum here is that those individuals who have the background and training necessary to meet Yunus's requirements for "holistic" educators are unlikely to be postgraduate alumni of western business schools. Further, given the serious differences in orientation between a typical "MBA" and $\alpha$ "social MBA" with respect to risk or return and agency considerations, it is unclear whether such faculty would be successful given the diverse moti- 
vations and interests of MBA students as well as the current faculty training, orientation, and organizational or promotional structure of the typical western business schools.

Yunus believes that if societies change their mind-sets to teach students that the goal of education is not to get rich but to enrich one's life by helping others, this business model could drastically reduce poverty in this century. And then, as he said when accepting the Nobel Prize, "the only place you would be able to see poverty is in the poverty museums." That may be true but first, he will have to overcome the challenges of incorporating the not-for-profit or personal gain orientation of the social business.

\section{REFERENCES}

Alchian, A., \& Demsetz, H. 1972. Production, information costs, and economic organization. American Economic Review, 62: 777-795.

Baumol, W. J. 2010. The microtheory of innovative entrepreneurship. Princeton, NJ: Princeton University Press.

Dacin, P. A., Dacin, M. T., \& Matear, M. 2010. Social entrepreneurship: Why we don't need a new theory and how we move forward from here. Academy of Management Perspectives, 24: 37-57.

Foundation Center. 2011. Tools and resources for assessing social impact (TRASI). Available at http://trasi.foundation center.org/. Accessed on December 3, 2011.

Hansmann, H. 1988. Ownership of the firm. Journal of Law, Economics and Organizations, 4: 267-304.

Jensen, M., \& Meckling, W. 1976. Theory of the firm: Managerial behavior, agency costs and ownership structure. Journal of Financial Economics, 3: 305-360.

Jensen, M., \& Murphy, K. 1990. CEO incentives: It's not how much you pay but how. Harvard Business Review, 68: 138-149.

Knaupp, A. E. 2005. Survival and longevity in the business employment dynamics database. Monthly Labor Review, 128: $50-56$.

Lepoutre, J., Justo, R., Terjesen, S., \& Bosma, N. In press. Designing a global standardized methodology for measuring social entrepreneurship activity: The Global Entrepreneurship Monitor social entrepreneurship study. Small Business Economics. Retrieved from http://rd.springer.com/article/10. 1007/s11187-011-9398-4

Mair, J., \& Martí, I. 2006. Social entrepreneurship research: A source of explanation, prediction and delight. Journal of World Business, 41: 36-44.

Manne, G. 1999. Agency costs and the oversight of charitable organizations. Wisconsin Law Review, 2: 227-277.

National Center for Charitable Statistics (NCCS). 2011. Assessing births and deaths of nonprofit organizations (method note). Available at http://nccsdataweb.urban.org/knowledge base/detail.php?linkID $=174 \&$ category $=118 \&$ xrefID $=3269$ $\&$ close $=0$. Accessed on December 3, 2011.
Ottenhoff, B. 2010. Shedding light on changes in the sector. Available at http://ceo.guidestar.org/2010/08/02/sheddinglight-on-changes-in-the-sector/. Accessed on December 3, 2011.

Short, J. C., Moss, T. W., \& Lumpkin, G. T. 2009. Research in social entrepreneurship: Past contributions and future opportunities. Strategic Entrepreneurship Journal, 3: 161-194.

Small Business Administration (SBA). 2011. Advocacy small business statistics and research.

Terjesen, S., Lepoutre, J., Justo, R., \& Bosma, N. 2012. Global entrepreneurship monitor: Social entrepreneurship study. Available at www.gemconsortium.org. Accessed July 15, 2012.

Tracey, P., \& Phillips, N. 2007. The distinctive challenge of educating social entrepreneurs: A postscript and rejoinder to the special issue on entrepreneurship education. Academy of Management Learning and Education, 6: 264-271.

Yunus, M. 2010. Building social business: The new kind of capitalism that serves humanity's most pressing needs. New York: Public Affairs.

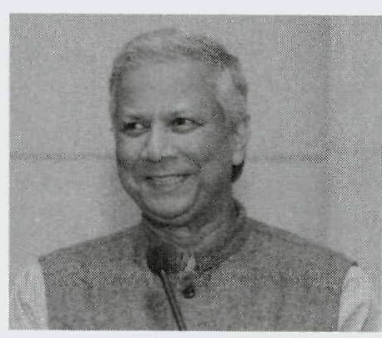

Nobel Laureate Muhammad Yunus

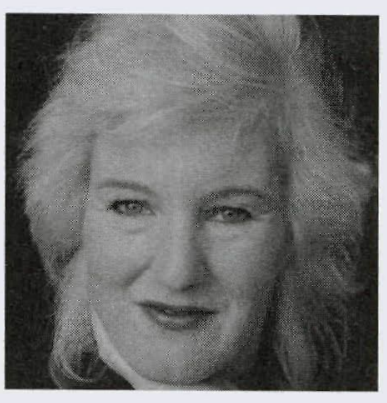

Jill Kickul is the director of the program in social entrepreneurship in the Berkley Center for Entrepreneurship and Innovation at New York University Stern School of Business. She obtained her $\mathrm{PhD}$ from Northern Illinois University in Industrial/ Organizational Psychology. Her research interests include social entrepreneurship, impact investing, and measuring social impact.

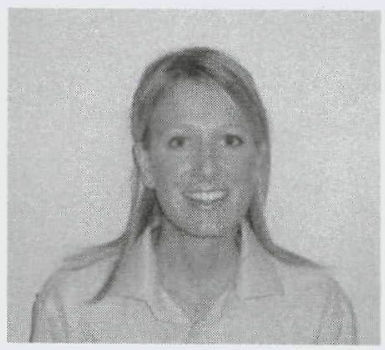

Siri Terjesen is an assistant professor of management and entrepreneurship at Indiana University. She obtained a $\mathrm{PhD}$ from Cranfield and a Master's from Norges Handelshøyskole. Siri is a coauthor of Global Entrepreneurship Monitor's Social Entrepreneurship Activity report, the world's largest study of social entrepreneurship prevalence. Her research interests are entrepreneurship, international business, and strategy. 


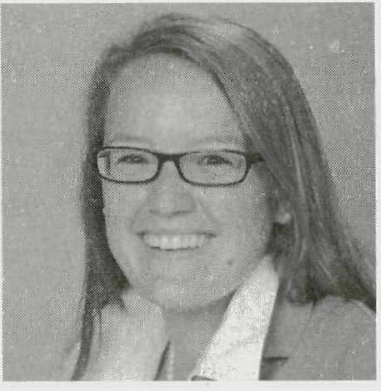

Sophie Bacq is an assistant professor in the College of Business Administration at Northeastern University in Boston. She earned her $\mathrm{PhD}$ in management from Université catholique de Louvain in Belgium. Her research interests include social entrepreneurship, governance and management issues in hybrid organizations, and international new ventures.

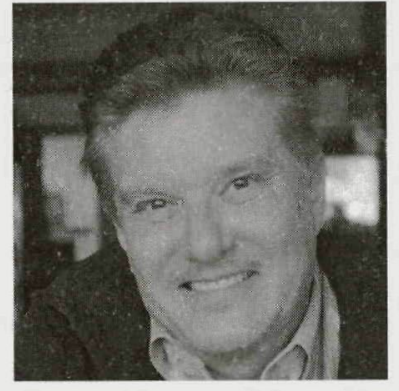

Mark Griffiths is the Jack Anderson Professor of Finance, at Miami University's Farmer School of Business. Professor Griffiths obtained his $\mathrm{PhD}$ (Finance) from the Richard Ivey School of Business at the University of Western Ontario in Canada. He investigates issues in money market microstructure, financial risk management and entrepreneurship. 
Copyright of Academy of Management Learning \& Education is the property of Academy of Management and its content may not be copied or emailed to multiple sites or posted to a listserv without the copyright holder's express written permission. However, users may print, download, or email articles for individual use. 